

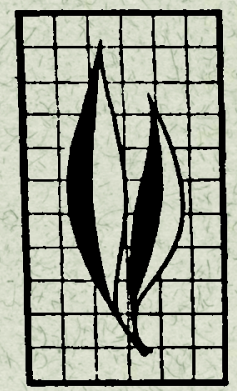

Injection of bacteria into tobacco leaves resulted in several reactions: typical hypersensitivity (HR), "greasy" hypersensitivity, delayed necrosis, chlorosis, hypertrophy, and occasionally leaflet formation. The type of reaction depended upon the species of bacteria used, the numbers injected into the leaf, and the environmental conditions under which the tests were conducted.

Most phytopathogenic fluorescent pseudomonads, xanthomonads, and several erwinias caused typical hypersensitivity when introduced in large numbers, delayed necrosis when in moderate numbers, and chlorosis when in small numbers. "Greasy" hypersensitivity was induced by many of the soft-rotting pathogens. Under low light conditions, agrobacteria caused hypertrophy and leaflet formation and, occasionally, death. The temperature at which plants were maintained both before and after injection greatly affected the type of host response with most organisms. High temperatures favor induction of $\mathrm{HR}$ by Pseudomonas solanacearum; low temperatures induction by $P$. syringae and $P$. phaseolicola. Preconditioning plants at $16^{\circ} \mathrm{C}$ before infiltration and maintaining plants at $32^{\circ} \mathrm{C}$ after infiltration enhanced $\mathrm{HR}$ formation by xanthomonads in most cases. The rapidity and effect of temperature on HR caused by xanthomonads differed among four varieties of tobacco. Nicotiana glutinosa was the only tobacco in which HR was induced by all xanthomonads. Expression of HR in this variety, however, took 36 to 48 hours to be expressed, instead of the more usual 6 to 20 hours. The numbers of bacteria required for $\mathrm{HR}$ under optimum conditions ranged from approximately $1.0 \times 10^{6}$ for $P$. syringae to $1.5 \times 10^{8}$ for $P$. phaseolicola, $P$. glycinea, and $P$. savastanoi among the pseudomonads, and to $3.0 \times 10^{\prime}$ for Erwinia amylovora.

\section{THE AUTHORS:}

D. C. Hildebrand is Associate Research Plant Pathologist, Department of Plant Pathology, Berkeley.

Beverly Riddle is Laboratory Technician, Department of Plant Pathology, Berkeley. 


\title{
Influence of Environmental Conditions on Reactions Induced by Infiltration of Bacteria into Plant Leaves ${ }^{1}$
}

\begin{abstract}
The number of bacteria needed to cause the hypersensitive (HR) or other necrotic responses in plant leaves was determined often by the environmental conditions under which the plant was grown prior to and after intromission of the bacteria into the intercellular spaces. Low temperatures reduced the number of Pseudomonas syringae, $P$. phaseolicola, and $P$. savastanoi cells required for HR whereas they increased the cell numbers required with $P$. solanacearum. Temperature and the tobacco species used affected induction of HR by xanthomonads. The amount of light influenced the type of response induced by agrobacteria with a necrotic response occurring under conditions of darkness.
\end{abstract}

\section{INTRODUCTION}

A hypersensitive Reaction (HR), induced when large numbers of certain bacteria are introduced into the intercellular spaces of plant leaves (Klement et al., 1964) is routinely used to aid in the identification of bacterial pathogens (Lelliott et al., 1966). This reaction is characterized by rapid necrotization, wherein the leaf tissue collapses and dries out about eight to 24 hours after infiltration of the bacteria. The induction of the HR is typical of many pseudomonads, xanthomonads, and $E r$ winia amylovora.

Although considerable reliance is placed in the HR to help identify bacterial plant pathogens, little is known about the parameters of the reaction. Questions that commonly arise include the following: (i) Are all pathogens equal in their ability to cause hypersensitivity? (ii) How do environmental factors such as temperature and light affect the reaction? (iii) Is the HR easily recognized, or are there other reactions which might be confused with the HR? (iv) Do all plants behave similarily upon injection of an incompatible pathogen into their intercellular spaces? Answers to these questions are needed to fully evaluate the reliability of the HR as a method of identification. Consequently, these studies were conducted to help answer the above questions and to assist in defining what constitutes an HR.

\section{Temperature effect upon HR reactions}

Previous studies indicated that high temperatures favored the development of the HR by xanthomonads (Schroth and Hildebrand, 1967) and Pseudomonas solanacearum (Sands et al., 1970), the latter being confirmed by Lozano and Sequeira (1970). In contrast, unpublished results have been cited (Klement and Goodman, 1967) which indicate that temperatures of $36^{\circ} \mathrm{C}$ or higher prevent the HR. Thus, an investigation was begun to examine the effect of temperature in more detail.

${ }^{1}$ Submitted for publication March 10, 1971. 
TABLE 1

STRAINS OF PATHOGENS USED IN THIS STUDY AND THEIR SOURCES

\begin{tabular}{|c|c|c|}
\hline Pathogen & $\begin{array}{c}\text { Strain } \\
\text { designation }\end{array}$ & Origin \\
\hline \multicolumn{3}{|l|}{ Agrobacterium } \\
\hline A. tumefaciens......... & CG14 & ICPB* TT103 \\
\hline A. tumefaciens........ & CG41 & ICPB TT131 \\
\hline A. tumefaciens......... & CG45 & Eu-7, received from R. S. Dickey, Cornell, N.Y., 1964 \\
\hline A. tumefaciens......... & CG68 & UCBPP isolated from rose, Berkeley, Calif. \\
\hline A. tumefaciens........ & CG69 & UCBPP isolated from eucalyptus, 1969 \\
\hline A. tumefaciens........ & Eu-8 & Received from R. S. Dickey, Cornell, N.Y., 1964 \\
\hline A. tumefaciens......... & Kerr 22 & Received from C. I. Kado, Davis, Calif., 1969 \\
\hline A. tumefaciens........ & Kerr 27 & Received from C. I. Kado, Davis, Calif., 1969 \\
\hline A. radiobacter......... & AR-15 & ICPB TR102 \\
\hline A. rhizogenes........ & HR-1 & ICPB TR108 \\
\hline \multicolumn{3}{|l|}{ Erwinia } \\
\hline E. amylovora.......... & FB-1 & UCBPP, isolated from cotoneaster, 1967 \\
\hline E. amlyovora......... & FB-9 & UCBPP, isolated from apple, Orinda, Calif., 1966 \\
\hline \multicolumn{3}{|l|}{ Pseudomonas } \\
\hline$P$. coronafaciens........ & \#8 & NCPPB 1348 \\
\hline P. glycinea........... & Glyc 564 & Received from C. Leben, Wooster, Ohio, 1968 \\
\hline P. glycinea.......... & $\mathrm{R}-4$ & Received from B. W. Kennedy, St. Paul, Minn., 1967 \\
\hline P. lachrymans........ & PL-1 & NCPPB 277 \\
\hline P. phaseolicola........ & HB-16 & G-2, received from R. G. Grogan, Davis, Calif., 1967 \\
\hline P. phaseolicola........ & HB-28 & Race 1 , received from J. I. Natti, Geneva, N.Y., 1967 \\
\hline P. phaseolicola......... & HB-36 & UCBPP, isolated from bean, Salinas, Calif., 1964 \\
\hline P. savastanoi......... & OK-22 & NEAP E-4 \\
\hline P. solanacearum....... & $\# 3$ & B139, received from I. Buddenhagen, 1967 \\
\hline P. solanacearum....... & $\# 8$ & H1527-SFR, received from I. Buddehnagen, Honolulu, Hawaii, 1968 \\
\hline P. solanacearum........ & $\# 10$ & P-28-T, received from I. Buddenhagen, Honolulu, Hawaii, 1968 \\
\hline P. syringae. . . . . . . & $\mathrm{S}-3$ & UCBPP, isolated from pear, Berkeley, Calif., 1963 \\
\hline P. syringae.......... & S-9 & UCBPP, isolated from plum, Santa Rosa, Calif., 1957 \\
\hline$P$. syringae........... & S-36 & UCBPP, isolated from pear, Orinda, Calif., 1967 \\
\hline P. syringae.......... & 620 & Received from C. Leben, Wooster, Ohio, 1968 \\
\hline P. tomato........... & P. tom. 1 & UCPBB, isolated from tomato, Salinas, Calif., 1967 \\
\hline P. tomato............ & P. tom. 8 & UCPBB, isolated from tomato, 1961 \\
\hline \multicolumn{3}{|l|}{ Xanthomonas } \\
\hline X. campestris......... & $\mathrm{XC}-2$ & $\mathrm{UCPBB}$ \\
\hline$X$. dieffenbachiae...... & XD-1 & UCPBB, isolated from dieffenbachiae, San Francisco, Calif., 1967 \\
\hline$X$. fragariae. ......... & $\mathrm{XE}-32$ & UCPBB, isolated from strawberry, Salinas, Calif., 1966 \\
\hline$X$. fragariae. . ........ & $\mathrm{XF}-102$ & ICPB \\
\hline$X$. incanae........... & SI-3 & 503, received from M. T. Lai, Sacramento, Calif., 1970 \\
\hline X. phaseoli.......... & $\mathrm{XP}-2$ & ICPB \\
\hline X. pruni............. & & UCPBB \\
\hline$X$. vesicatoria $\ldots \ldots \ldots$ & XVG-36 & $\mathrm{UCPBB}$ \\
\hline$X$. vitians........... & X. lett. & UCPBB, isolated from lettuce, Salinas, Calif., 1964 \\
\hline Xanthomonas sp...... & X. ti. & Received from A. H. McCain, Berkeley, Calif. \\
\hline
\end{tabular}

*Abbreviations used:

NEAP-Estacaco Agronomica Nacional (Maria de Lourdes d'Oliveria), Oerias, Portugal.

ICPB-International Collections of Phytopathogenic Bacteria, Department of Bacteriology (M. P. Starr), University of California, Davis.

NCPPB - National Collection of Plant Pathogenic Bacteria, Plant Pathology Laboratory (R. A. Lelliott), Harpenden Herts, England.

UCBPP-Department of Plant Pathology, University of California, Berkeley.

Combined with this investigation were studies to determine the effect of preconditioning of the host upon the HR and of the numbers of bacteria required to induce HR.

Four suspensions (turbidity reading of 160 on a Klett-Summerson colorimeter using a green filter \#54 and dilutions of $1 / 10,1 / 100$, and $1 / 1000$ ) were prepared of cells of various pseudomonads, xanthomonads, and erwinias (Table 1) grown on King's medium 
B (King et al., 1954) or YDCP (Leben et al., 1970). These suspensions were injected with a hypodermic syringe into alternate intercostal areas of leaves of Glurk (Nicotiana glutinosa L. $\times$ N.tabacum L. [Samsun $\times$ Xanthi] cv. Turkish, nc. tobacco plants which had been preconditioned under natural light for four days or longer in constant temperature $\left( \pm 2^{\circ} \mathrm{C}\right)$ cubicles of $16,21,27$, and $32^{\circ} \mathrm{C}$. Immediately after injection, the plants were moved to different temperature cubicles. The degree of HR which occurred was determined after $24,48,72$, and 168 hours.

The response to changes in temperature were divided into there general types: those where temperature had no effect on HR under the range tested (Type I), those where higher temperatures generally enhanced HR (Type II), and those where lower temperature generally enhanced the reaction (Type III). These three types of responses are illustrated in table 2 by the data obtained for $P$. tomato strain P. tom. 8 (Type I), $P$. solanacearum \#8 (Type II), and $P$. syringae S-9 (Type III). Preconditioning also had an effect upon the HR. For example, more bacteria often were required to induce $H R$ in the Type III response at all incubation temperatures when the plants were preconditioned at $32^{\circ} \mathrm{C}$. Another effect noted was that the HR ofter tended to be less severe if plants were maintained at the same temperature before and after infection of the bacteria.

Different strains differed in their ability to induce HR. The bacteria were divided into groups depending upon the temperature response type of HR they produced and the minimum number of cells required to produce complete killing of the infiltrated portion of the leaf within 72 hours was determined (table 3 ). Examination of the groupings indicated that the number of bacteria required for $\mathrm{HR}$, and the temperature response type generally were charac- teristic for each species. For example, the two strains of Erwina amylovora and the two strains of $P$. tomato produced a Type I response. However, it generally took 20 to 200 times as many cells of $E$. amylovora as cells of $P$. tomato to induce HR. Individual strains of species differed somewhat from each other, both in the number of cells needed to induce the HR and in their specific response to temperature changes. The same number of cells of $P$. syringae isolates S-3 and S-9 caused HR when plants were kept at $32^{\circ} \mathrm{C}$ or moved to $32^{\circ} \mathrm{C}$ from $27^{\circ}$ or $21^{\circ} \mathrm{C}$; but when moved to $32^{\circ}$ from $16^{\circ} \mathrm{C}$, ten times more cells of S-3 than of S-9 were required for HR.

The bacteria were grouped according to the general type of response they induced on the basis of all of the data obtained, including the additional dilutions and the length of time and amount of killing which occurred.

\section{Host variety effect upon injection reaction}

Xanthomonad strains (table 1) were used to determine the effect of host variety upon the HR, and of the interaction with temperature. Four tobacco varieties were used: Glurk, N. tabacum, $N$. rustica L., and $N$. glutinosa. All plants were preconditioned in the constant-temperature greenhouse cubicles for four days prior to injection with suspensions of 160 Klett units of the xanthomonads. The pre- and post-infiltration temperatures used in this test were $16^{\circ}$ to $16^{\circ} \mathrm{C}, 16^{\circ}$ to $32^{\circ} \mathrm{C}, 32^{\circ}$ to $16^{\circ} \mathrm{C}$, and $32^{\circ}$ to $32^{\circ} \mathrm{C}$.

The various tobacco varieties all reacted differently in these tests with respect both to the strain of the pathogen used and to the effect of temperature (table 4). In general, incubation of plants at $16^{\circ} \mathrm{C}$, regardless of the preconditioning temperature, prevented the $\mathrm{HR}$. Preconditioning the plants at $16^{\circ} \mathrm{C}$ and incubating them at $32^{\circ} \mathrm{C}$ after injection was most favorable for the HR. 


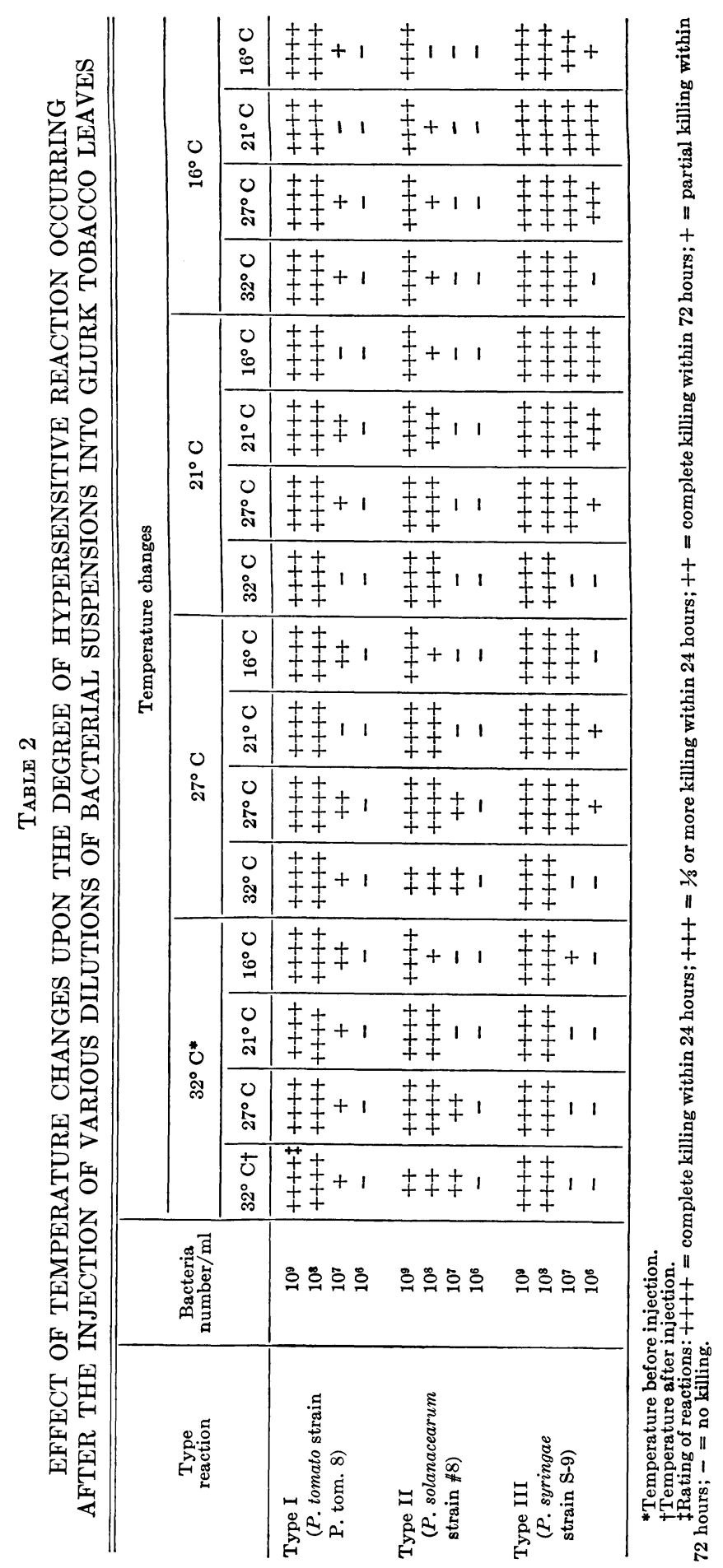




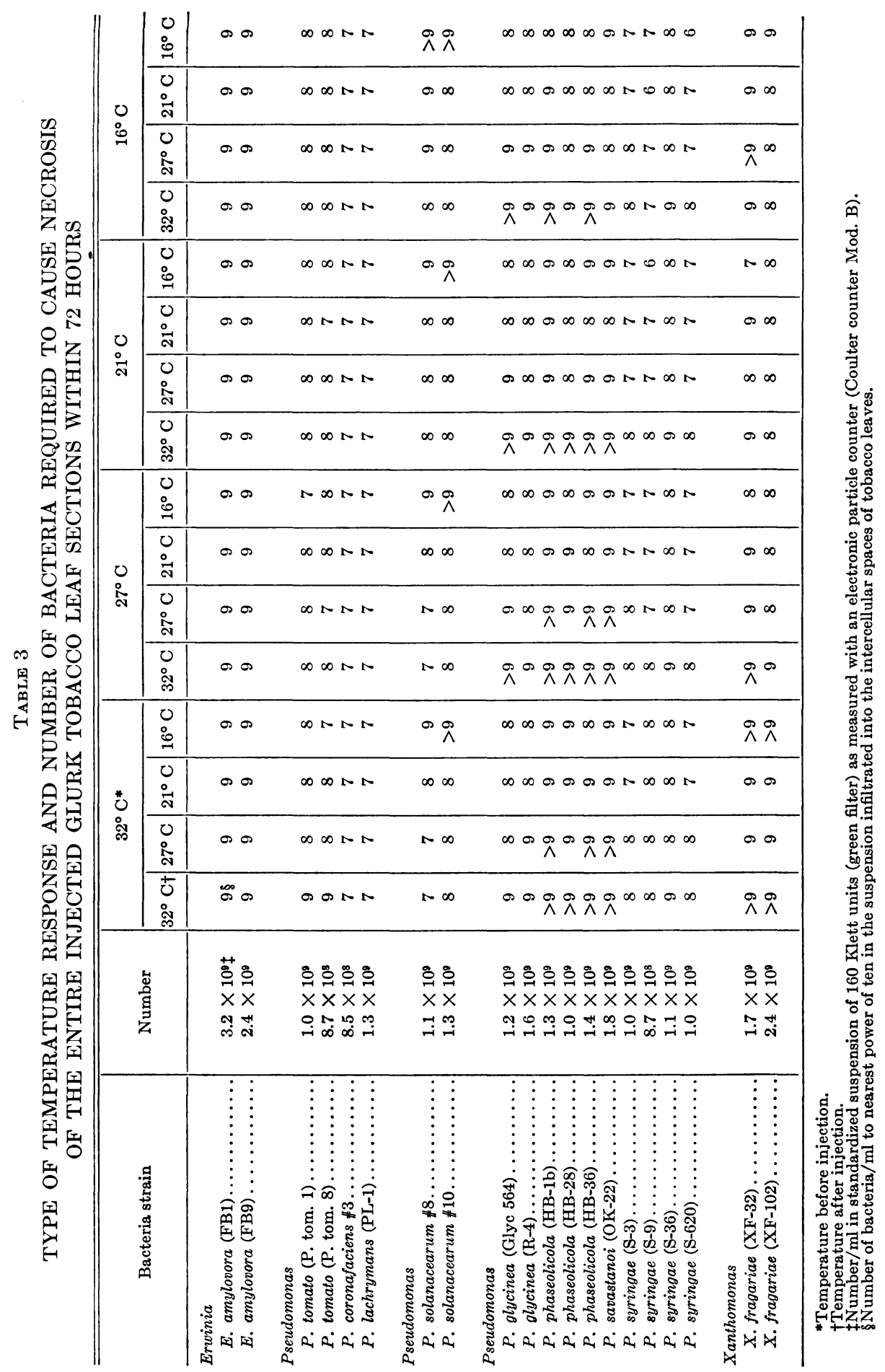




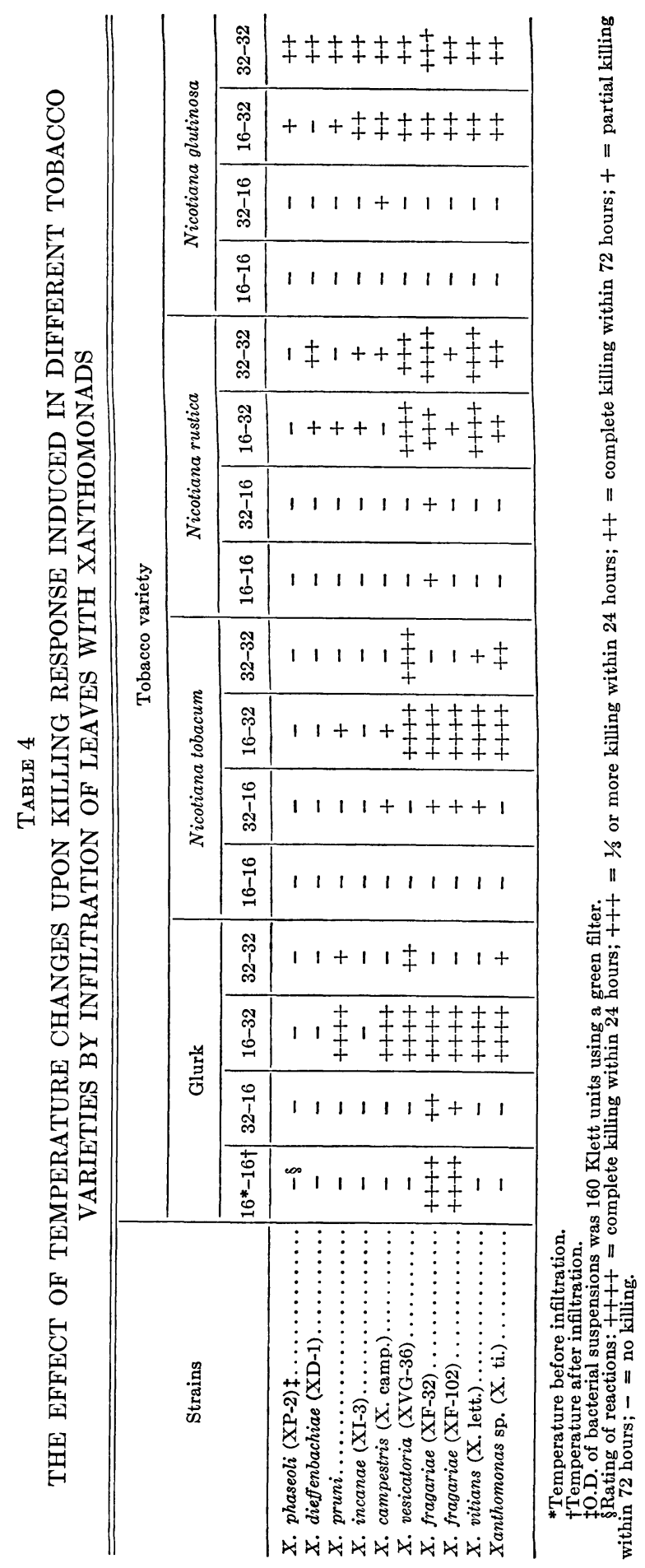


However, maintaining the plants at $32^{\circ} \mathrm{C}$ before and after injection generally prevented HR in Glurk and $N$. tabacum, whereas HR was severe in the $N$. rustica and $N$. glutinosa varieties. The most sensitive indicator plant appeared to be $N$. glutinosa, although the HR in this plant was delayed, and death usually occurred after approximately 40 rather than after the common 18 hours.

\section{Effect of light upon reactions induced by $A$ grobacterium tumefaciens and other bacteria}

Inoculation of plant leaves using the carborundum inoculation method has resulted in the formation of tumors (Lippincott and Heberlein, 1965). Therefore it is of interest to determine the effect of injection of $A$. tumefaciens and related bacteria into leaves. For comparison, several pseudomonads and xanthomonads were also tested. The tests were conducted primarily in growth chambers, although one series was conducted in a greenhouse under constant temperature of $27^{\circ} \pm 2^{\circ} \mathrm{C}$. The growth chambers were programmed for temperatures of $16^{\circ}$ or $27^{\circ} \mathrm{C}$ with lighting of 150 or $300 \mathrm{ft}$-c on a continuous, or alternating, 12-hour on/12-hour off, or total-darkness basis. Glurk tobacco plants were maintained for four days before infiltration at the conditions under which the tests were to be conducted. The bacterial suspensions were prepared from 24- to 48-hour cultures grown on King's medium B or YDCP and standardized at 200 Klett units (green filter). Reactions generally were recorded nine to 14 days but, occasionally up to 30 days after infiltration.

The reaction of Glurk tobacco to the injection of a cell suspension of agrobacteria into leaves depended upon the environmental conditions under which the plants had been maintained after injection. Every isolate, whether virulent or avirulent, produced some killing in the infiltrated leaf panel under conditions of total darkness and temperature of $27^{\circ} \mathrm{C}$ (table 5). On the other hand, no reactions were observed when the plants were maintained under continuous light (150 ft-c) at $27^{\circ} \mathrm{C}$. Marked chlorosis occurred under several conditions. A thickening of leaves inoculated with certain isolates of $A$. tumefaciens was observed in plants maintained in the greenhouse at $27^{\circ} \mathrm{C}$ during the winter, but not during the summer. Microscopic examination indicated that the thickening was due to hypertrophy, not hyperplasia. Occasional tumors occurred on some of these leaves, and plantlets were rarely formed. The tumors and plantlets appeared to originate from vein tissue and not from leaf lamina tissue.

The reactions induced by the xanthomonads were also influenced by light. As with the agrobacteria, there appeared to be more killing under conditions of continuous darkness. Light appeared to have little effect on the reactions caused by the pseudomonads.

\section{Host reactions types resulting from injection of bacteria into plant leaves}

It became obvious during the preceding tests that $\mathrm{HR}$ is not the only alternative to a true pathogenic response which may occur upon injection of bacteria into plant leaves. Usually the various reactions and conditions under which the reactions occurred were characteristic for a given group of bacteria, and, consequently, they can be used to a limited extent as an aid to identification of a pathogen. Occasionally they can be confused with a true pathogenic response, and, consequently, observations of host reactions must be interpreted with caution. A summary of the reactions which were observed and their characteristics is presented in table 6 , as an aid to identification of pathogens and interpretation of plant responses to the infiltration of bacteria. 


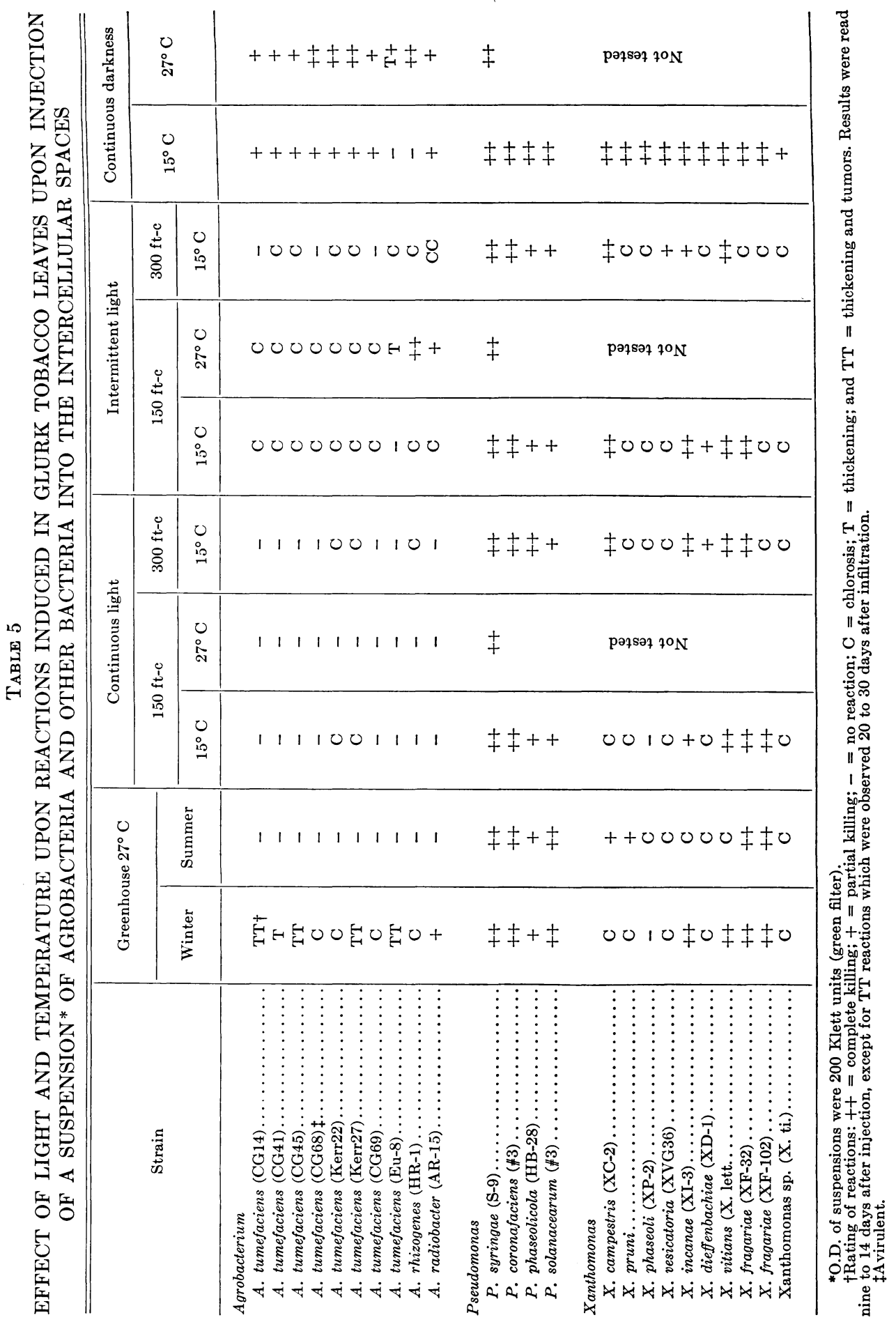


TABLE 6

REACTION OF TOBACCO (GLURK) LEAVES INDUCED BY INJECTION OF SUSPENSIONS OF INCOMPATIBLE PATHOGENS INTO THE INTERCELLULAR SPACES OF LEAVES

\begin{tabular}{|c|c|}
\hline Reaction type & Characterization of reaction \\
\hline Hypersensitivity (typical).... & $\begin{array}{l}\text { Reaction characterized by rapid necrosis (within } 6-20 \text { hours after injection) of in- } \\
\text { filtrated portion of leaf. The killed section of the leaf remains green or becomes } \\
\text { slightly brown. This reaction occurs after infiltration of large numbers of Erwinia } \\
\text { amylovora, occasionally other erwinias including some isolates of E. quercina and } \\
E \text {. carotovora, all species of the Pseudomonas syringae group (Sands et al., 1970), } \\
P \text {. solanacearum and many xanthomonads. Occurrence of the reaction is sensitive to } \\
\text { light and temperature conditions. Usually associated with incompatible pathogens, } \\
\text { but can occur also with compatible pathogens. }\end{array}$ \\
\hline Hypersensitivity ("greasy").. & $\begin{array}{l}\text { Reaction characterized by rapid necrosis ( } 12-20 \text { hours after injection) of infiltrated } \\
\text { portion of leaves. Large numbers of cells are required. The killed section of the leaf } \\
\text { becomes "greasy" in appearance. This reaction occurs of ten-but not always-with } \\
\text { some isolates of the Erwinia and nonfluorescent pseudomonad, soft-rotting groups. }\end{array}$ \\
\hline Delayed necrosis........... & $\begin{array}{l}\text { Reaction characterized by a slow necrosis ( } 30-192 \text { hours after injection) of infiltrated } \\
\text { portion of leaf. The killed section of ten becomes chlorotic before dying. The color of } \\
\text { the dead section is brown. This reaction occurs with most strains which cause a typical } \\
\text { HR when only moderate numbers of cells are infiltrated, or if environmental con- } \\
\text { ditions not as favorable for HR are selected. In addition, injection of } A \text {. tumefaciens } \\
\text { or A. rabiobacter will produce this result if the injected plants are kept under low } \\
\text { light or total darkness. }\end{array}$ \\
\hline $\begin{array}{l}\text { Hypertrophy and leaflet } \\
\text { formation } . . . \cdots \cdots \cdots \cdots\end{array}$ & $\begin{array}{l}\text { This reaction occurs with isolates of } A \text {. tumefaciens and } A . \text { radiobacter under moderate } \\
\text { light. Hypertrophy is common, whereas leaflet formation is observed only rarely. }\end{array}$ \\
\hline 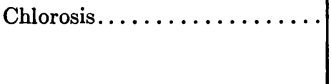 & $\begin{array}{l}\text { This reaction is induced by all bacteria including saprophytes and pathogens if } \\
\text { sufficient numbers are introduced into the leaf. Numbers, however, must be fewer } \\
\text { than those required to cause one of the killing reactions. }\end{array}$ \\
\hline
\end{tabular}

\section{Discussion}

The HR induced by bacteria has been described as a rapid necrosis of tissue occurring 8 to 24 hours after introduction or large numbers of a pathogen into the intercellular spaces of the plant. Although the onset of the HR can be delayed, it still is characterized by the rapidity with which the infiltrated tissue collapses and dies. We found, however, that in many cases a slow necrosis will occur under certain conditions. Sometimes this involves only the selection of a different plant. Thus the questions arise whether this reaction can be called HR and whether nonpathogens might induce the same reaction under certain conditions. We did not test nonpathogens, but it is conceivable that many with the proper manipulation could cause death in plants. An example of this was established by Lovrekovich and Lovrekovich (1970) who demonstrated that with proper manipulation, $P$. fluorescens can kill a tobacco leaf.

Our results indicate that tests for HR should be conducted under several conditions if any reliance is to be placed on statements that an organism does or does not cause HR. Rather, such a statement may be a reflection of the range of conditions under which $\mathrm{HR}$ is induced by an organism. Thus our original report that $E$. quercina does not induce HR (Hildebrand and Schroth, 1967) was erroneous, as we now find HR induction by this organism after only slight changes were made in conditions under which the tests were conducted. Certainly many of the xanthomonads appear to induce the HR under a much 
narrower range of conditions than most pseudomonads. An exception to this appears to be $X$. fragariae which induces HR under a range of conditions similar to that of pseudomonads.

Our findings also provide evidence that different pathogens have different systems causing reactions which can be grouped under the term HR. In some cases, this evidence concerns the appearance of the dead plant part such as the "greasy" versus "typical" HR. Further indications that different pathogens have different systems for inducing $\mathrm{HR}$ and that this directly involved interactions with the host plant were provided by the findings that the number of bacteria required for $\mathrm{HR}$ and the specific response to temperature changes were characteristic for various species of the pathogen. The characteristic responses to temperature could not be ascribed solely to an effect of temperature upon the pathogen because preconditioning the host at specific temperatures had a significant effect upon the induction of HR. This preconditioning effect was particularly pronounced when xanthomonads were tested against Glurk tobacco. HR in this case was enhanced if the plant had been preconditioned at what appears to be an unfavorable (for HR) temperature before being moved to the favorable temperature. In contrast, HR exhibited a tendency to be more severe if the plants were preconditioned at a temperature favorable for HR when pseudomonads were tested. A final indication that different bacteria have different systems for causing HR is the effect of light upon the reaction. Although darkness increases the lethal effect of xanthomonads, it apparently has little effect on the HR causcd by pseudomonads.

Several possibilities concerning the mechanisms of killing are suggested by examination of the reactions which occurred. The association of soft-rotting organisms, both erwinias and pseudomonads, with the "greasy" HR suggests that pectolytic or similar enzymes may be a factor. A possibility with $A$. tumefaciens is the involvement of auxins. Formation of IAA or similar auxins by $A$. tumefaciens could result in the hypertrophy observed. Perhaps under the condition of darkness the levels of auxin formed became toxic and the infiltrated parts of the leaf were killed.

The HR is a test which has been extensively used in the recognition of phytopathogenic bacteria. It appears, however, that its full potential in this area has not been reached. Currently, each laboratory uses a different variety grown under a different set of conditions to test for HR. This lack of standardization perhaps does not affect results in many cases if only the capacity of an organism to induce HR is being tested. On the other hand, the ability of some organisms to cause HR is greatly influenced by the conditions under which tests are conducted, and considerable variation in results among laboratories would be expected. Furthermore, it appears that different species of bacteria react to different conditions in a characteristic manner, and that these characteristic reactions could be used in species identification. The full potential of these tests, however, will not be realized until laboratories standardize the condition under which HR is tested. 


\section{LITERATURE CITED}

Hildebrand, D. C., and M. N. Schroth

1967. A new species of Erwinia causing the drippy nut disease of live oaks. Phytopathology $57: 250-53$.

KING, E. O., M. K. WARD, and D. E. RANEX

1954. Two simple media for the demonstration of pyocyanin and fluorescin. Jour. Lab. Clin. Med. 44:301-07.

Klement, Z., Farkas, G. L., and L. LovRekovich

1964. Hypersensitive reaction induced by phytopathogenic bacteria in the tobacco leaf. Phytopathology 54:474-77.

KLEMENT, Z., and R. N. GoodmaN

1967. The hypersensitive reaction to infection by bacterial plant pathogens. Ann. Rev. Phytopathol. 5:17-44.

LEBEN, C., M. N. Schroth, and D. C. HiLdEBRAND

1970. Colonization and movement of Pseudomonas syringae on healthy bean seedlings. Phytopathology 60:677-80.

Lelliott, R. A., E. Billing, and A. C. Hayward

1966. A determinative scheme for the fluorescent plant pathogenic pseudomonads. Jour. Appl. Bacteriol. $29: 470-89$.

LIPPINCOTT, J. A., and G. T. HEBERLEIN

1965. The induction of leaf tumors by Agrobacterium tumefaciens Amer. Jour. Botan. $52: 396-403$.

LOVREKOVICH, L., and H. LOVREKOVICH

1970. Tissue necrosis in tobacco caused by a saprophytic bacterium. Phytopathology 60:1279 80.

Lozano, J. C., and L. SEqueira

1970. Differentiation of races of Pseudomonas solanacearum by a leaf infiltration technique. Phytopathology $60: 833-38$.

Sands, D. C., M. N. Schroth, and D. C. Hildebrand

1970. Taxonomy of phytopathogenic pseudomonads. Jour. Bacteriol. 101:9-23.

Schroth, M. N., and D. C. HILdEBRAND

1967. Host reaction as a method of differentiating bacterial plant pathogens. Proc. 2nd Internal. Conf. Phytopathogenic Bacteria, Oeiras. Portugal, \#23. 

The journal HILGARDIA is published at irregular intervals, in volumes of about 650 to 700 pages. The number of issues per volume varies.

Single copies of any issue may be obtained free, as long as the supply lasts; please request by volume and issue number from:

\section{Agricultural Publications \\ University of California \\ Berkeley, California 94720}

The limit to nonresidents of California is 10 separate titles. The limit to California residents is 20 separate titles.

The journal will be sent regularly to libraries, schools, or institutions in one of the following ways:

1. In exchange for similar published material on research.

2. As a gift to qualified repository libraries only.

3. On a subscription basis $-\$ 7.50$ a year paid in advance. All subscriptions will be started with the first number issued during a calendar year. Subscribers starting during any given year will be sent back numbers to the first of that year and will be billed for the ensuing year the following January. Make checks or money orders payable to The Regents of The University of California; send payment with order to Agricultural Publications at above address. 